\title{
Distribution of histamine, 5-hydroxytryptamine, and other pharmacologically active substances in the human stomach
}

\author{
J. G. MURRAY AND J. H. WYLLIE 1 \\ From the Departments of Surgery, King's College Hospital Medical School \\ and University of Aberdeen
}

EDITORIAL SYNOPSIS The distribution of histamine and 5-hydroxytryptamine (5-HT) has been studied in the mucosa, submucosa, and muscle of human stomachs obtained at operations for duodenal ulcer, gastric ulcer, and cancer of the stomach. Histamine concentrations are not clearly correlated with pathology. Nor do they support the idea that histamine is stored close to acidsecreting cells and is, therefore, likely to be the specific chemostimulator of acid secretion.

The distribution of 5-hydroxytryptamine is different from that of histamine and does not correspond to that described for argentaffin cells. 5-Hydroxytryptamine concentrations are low in cases with cancer of the stomach.

A brief description is given of two other pharmacologically active substances present in the wall of the stomach.

For many years it has been generally believed that histamine is the physiological chemostimulator of the acid-secreting cells in the stomach. The idea gained great impetus from the work of Babkin and others (Björkman, Norden, and Uvnäs, 1943; Linde, 1950; Babkin, 1950). In a review in 1956 Code stated: 'Stimulation of gastric secretion is a function of histamine. No other chemostimulator is interposed between histamine and the parietal cell. Histamine is the final, common local chemostimulator of the parietal cells in the gastric mucosa'. Nevertheless, the acceptance of this physiological role for histamine has not led to any major advance in the control of acid secretion. In this and the following paper we examine the hypothesis that histamine is the specific local chemostimulator of the acid-secreting cells in man. and concludin $y$ that it is false, we propose an alternative hypothesis.

Before a naturally occurring substance can be accepted as a specific local chemostimulator, and acetylcholine is perhaps our best model, the following criteria must be satisfied: 1 The substance must be stored in proximity to the effector cells. 2 The substance must be released during normal function of the effector cells. To demonstrate this it is usually necessary to collect the released substance. 3 Injec-

${ }^{1}$ Medical Research Council research assistant. tion of the substance under suitable conditions must mimic the physiological function. 4 In addition, one expects to find that physiological function and function induced by injection of the substance are affected similarly by inhibitory drugs. 5 After denervation the effector cells become hypersensitive to the substance.

This first paper is concerned with the distribution of histamine within the human stomach. The mechanism of secretion is discussed in the following article (Clark, Curnow, Murray, Stephens, and Wyllie, 1964).

\section{METHODS}

MATERIAL Human stomachs were obtained in the operating theatre as soon as they were removed from the patients. A specimen usually consisted of about twothirds of the stomach. It was opened along the greater curvature and rinsed under cold tap water. After removing small pieces for routine pathology, the specimen was placed in the deep freeze at $-15^{\circ} \mathrm{C}$. This was usually about 10 minutes after removal from the body.

PREPARATIONS Two methods of preparing the material were used.

1 Dissection technique Following the technique of Douglas, Feldberg, Paton, and Schachter (1951) the 
stomach wall was dissected into three macroscopic layers. These were muscularis externa, submucosa, and mucosa. Histology showed that the muscularis mucosae adhered to the glandularis mucosae. In specimens frozen with $\mathrm{CO}_{2}$-snow sizeable pieces of muscularis mucosae could sometimes be removed from the mucosa. This separation of mucosa and muscularis mucosae was always difficult, and it was always incomplete because the strands of muscularis mucosae which penetrate between the glands were necessarily left behind. This dissection technique was applied to the stomach wall of the body and pylorus. A part of each specimen was taken for histological examination. The specimen from the body was taken near the greater curve because pyloric-type mucosa frequently extends far up the lesser curve (Magnus, 1958). In cases with gastritis, dissection was more difficult than in cases with duodenal ulceration in which the stomach frequently appears normal on histological examination.

2 Sectioning technique Following the technique described by Feldberg and Harris (1953) for examination of stomach and intestinal mucosa of dogs, pieces of stomach wall consisting of mucosa and submucosa from both pyloric and body regions were sectioned on a freezing microtome. Sections were cut parallel to the surface of the mucosa with a thickness of $20 \mu$. They were collected in groups (usually nine at a time), the middle section in each group being spread on a glass slide, fixed, and stained with haematoxylin and eosin. The other sections were extracted for histamine as described below. Before sectioning began a piece from one edge of the specimen to be sectioned was removed for separate histological examination. This was fixed in $10 \%$ formalin in $0.9 \% \mathrm{NaCl}$. It was embedded in paraffin and cut in a plane at right angles to the surface of the mucosa.

\section{EXTRACTION}

ACID EXTRACTS These were made by the method of Douglas et al. (1951) in dissection experiments and by the method of Feldberg and Harris (1953) in sectioning experiments.

ACETONE EXTRACTS These were made by the method of Parratt and West (1957). Specimens so extracted were pieces of mucosa, submucosa, and muscle adjacent to those taken for acid extraction. Acetone extraction was not used in sectioning experiments.

\section{CHROMATOGRAPHY}

Ascending chromatograms were run on Whatman no. 1 paper in air at room temperature for about 100 minutes in a Universal tank (Aimer Products Ltd.) equilibrated with $100 \mathrm{ml}$. of $n$-butanol: glacial acetic acid: water mixture (60:15:25 volumes). They were dried for 20 minutes in a current of cold air and usually stored at $-15^{\circ} \mathrm{C}$. overnight before assay.

\section{ASSAY}

HISTAMINE Acid extracts were assayed for histamine content on guinea-pig ileum in an $8 \mathrm{ml}$. bath of oxygenated Tyrode solution at $37^{\circ} \mathrm{C}$. to which hyoscine hydrobromide was added in a concentration of $10^{-7} \mathrm{~g} . / \mathrm{ml}$. (Paton and Vane, 1963). Contractions were assumed to be due to histamine if they had a time course similar to those induced by histamine and if mepyramine maleate $\left(10^{-8} \mathrm{~g} . / \mathrm{ml}\right.$.) abolished them or reduced them in parallel with contractions caused by histamine.

5-HYDROXYTRYPTAMINE Acetone extracts were assayed for 5-HT content by the method of Vane (1957) using the same bath, temperature, and hyoscinized tyrode solution as was used for histamine assay.

Tyrode solution had the composition: $\mathrm{NaCl} 8.0$; $\mathrm{KCl} 0 \cdot 2: \mathrm{CaCl}_{2}$. $6 \mathrm{H}_{2} \mathrm{O} 0.396 ; \mathrm{Mg} \mathrm{Cl}_{2} .6 \mathrm{H}_{2} \mathrm{O} ; 0.0214$; $\mathrm{NaH}_{2} \mathrm{PO}_{4} .2 \mathrm{H}_{2} \mathrm{O} 0.05$; glucose 1.0; $\mathrm{NaHCO}_{3} 1.0 \mathrm{~g}$./L.

Throughout this paper doses of histamine and 5-hydroxytryptamine refer to the bases, and concentrations of mepyramine maleate, the 2-bromo derivative of lysergic acid diethylamine (BOL 148, Sandoz), and hyoscine hydrobromide refer to the stated salts. Histamine and 5-hydroxytryptamine used as standards were made up from histamine acid phosphate (British Drug Houses Ltd.) and 5-hydroxytryptamine creatinine sulphate (a gift from May and Baker, Ltd.).

\section{RESULTS}

DISSECTION TECHNIQUE Table I shows the results of histamine and 5-HT assays on mucosa, submucosa, and muscle from both body and pylorus of 16 stomachs. The figures given refer to micrograms of active base per gram of wet tissue. The cases are grouped according to the condition for which operation was performed: 1 duodenal ulceration (five cases); 2 both duodenal and gastric ulceration (three cases); 3 gastric ulceration (three cases); and 4 , cancer of the stomach (five cases). In taking the specimens, tissue in the immediate vicinity of a macroscopic pathological lesion was avoided.

Histamine There was no statistically significant difference between the mucosal histamine concentration in the body and that in the pylorus $(P=0.6)$. The average histamine concentration found in the body was $13.0 \mu \mathrm{g} . / \mathrm{g}$. and that in the pyloric mucosa was $14.6 \mu \mathrm{g} . / \mathrm{g}$. This result is incompatible with the view that there exists in the mucosa of the body of the stomach of man a peculiarly high concentration of histamine for the purpose of stimulating the acid-secreting cells.

The histamine content of submucosa of both body and pylorus is approximately half that of mucosa and twice that of the muscularis externa.

Feldberg and Harris (1953) showed that in dogs the muscularis mucosae of the body of the stomach contained a high concentration of histamine; they also pointed out that in performing the dissection the muscularis mucosae adhered to the mucosa and 
TABLE I

RESULTS OF HISTAMINE AND 5-HT ASSAYS ON EXTRACTS OF MUCOSA, SUBMUCOSA, AND MUSCLE OF 16 HUMAN STOMACHS Case Sex Age Diagnosis
No.

not to the submucosa. The question thus arose as to whether the high concentration of histamine in the mucosa in man was due to adherent muscularis. Preparations of practically pure muscularis mucosae were assayed and the results were as follows (values for adjacent mucosa in brackets): case 8, body, $6.2 \mu \mathrm{g} . / \mathrm{g}$. $(20.7 \mu \mathrm{g} . / \mathrm{g}$.); case 5 , body, $7.6 \mu \mathrm{g} . / \mathrm{g}$. (18.7 $\mu$ g./g.); pylorus $7 \cdot 2 \mu$ g./g. (13.0 $\mu$ g./g.). It was concluded that in man, as distinct from the dog, the muscularis mucosae is not particularly rich in histamine.

Tissue in the neighbourhood of an active ulcer was found to have a high content of histamine as follows: case 6, muscle beneath floor of ulcer, $7 \cdot 4 \mu \mathrm{g} . / \mathrm{g}$.; thickened serosa $5.5 \mu \mathrm{g} . / \mathrm{g}$.; case 9 , floor of ulcer $21.3 \mu \mathrm{g} . / \mathrm{g}$.; muscle beneath floor $19.0 \mu \mathrm{g} . / \mathrm{g}$.; thickened serosa $7 \cdot 3 \mu \mathrm{g} . / \mathrm{g}$. It is interesting that although actual tumour tissue appeared to contain less histamine than neighbouring mucosa (Table II) there was, apparently, no change in the histamine content of the atrophic mucosa in cases of cancer as compared with that in other cases.

5-Hydroxytryptamine The mucosa was always much richer in 5-HT than any of the other layers. In any given stomach, the pyloric mucosa was richer than the body mucosa. Values in peptic ulcer cases for body mucosa averaged $0.99 \mu \mathrm{g} . / \mathrm{g}$., those for pyloric mucosa $3.3 \mu \mathrm{g}$. $/ \mathrm{g}$. The cancer cases were excluded from this reckoning since it is clear that
5-HT ( $\mu g . / g$.

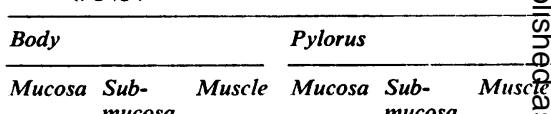

mucosa mucosa mucosa

$0.058 \overline{0}$

$\begin{array}{llllllll}7.0 & 4.2 & 1.3 & 0.089 & 0.027 & 2.0 & 0.19 & 0.058 . \\ 6.9 & 4.0 & 0.33 & 0.010 & 0.017 & 2.2 & 0.015 & 0.017\end{array}$

$\begin{array}{rrllllll}6.9 & 4.0 & 0.33 & 0.010 & 0.017 & 2.2 & 0.015 & 0.017 \text { 二 } \\ 13.2 & 4.6 & 0.28 & 0.14 & 0.12 & 3.8 & 0.29 & 0.031 \vec{\omega}\end{array}$

$\begin{array}{llllllll}13.2 & 4.6 & 0.28 & 0.14 & 0.12 & 3.8 & 0.29 & 0.031 \vec{\omega} \\ 34.0 & 5.6 & 0.38 & 0.085 & 0.10 & 7.4 & 0.46 & 0.22 \text { W }\end{array}$

$\begin{array}{lllll}0.008 & 0.010 & 0.76 & 0.008 & 0.0120\end{array}$

$9 \cdot 6 \quad 5 \cdot 2$

$5 \cdot 2$

$5 \cdot 1 \quad 3 \cdot 4$

$-\quad-$

0.010

$6 \cdot 3$

$-\frac{1}{\varepsilon}$

$\begin{array}{lllllll} & 0.33 & 0.050 & 0.020 & 2.9 & 0.073 & 0.013 \\ & 0.45 & 0.019 & 0.015 & 0.59 & 0.019 & 0.005 \\ & & & & & \\ 0.69 & 0.13 & 0.056 & 1.2 & 0.085 & 0.074 \\ 1.4 & 0.11 & 0.10 & 3.5 & 0.078 & 0.074 \\ 4.3 & 0.25 & 0.084 & 5.2 & 0.69 & 0.33 \\ 0.72 & 0.045 & 0.021 & 0.83 & 0.24 & 0.010 \\ 0.33 & 0.012 & 0.006 & 0.22 & 0.00 & 0.018 \\ & 0.10 & 0.028 & 0.000 & 0.42 & 0.12 & 0.016 \\ & - & - & - & 0.72 & 0.00 & 0.018 \\ 0.34 & - & 0.023 & - & - & - \\ 0.99 & 0.089 & 0.055 & 3.3 & 0.19 & 0.087\end{array}$

denal

gastric

ulcers

Carcin-

$\begin{array}{llllll}\text { oma } & 0.37 & 0.028 & 0.012 & 0.55 & 0.009\end{array}$

they have values of a different order of magnitude.

These results are in good agreement with those of Erspamer (1954a). The 5-HT content of submucosa and muscle was much lower than that of mucosa and was sometimes as low as $0.01 \mu \mathrm{g}$./g. which was near the limit of sensitivity of the assay technique.

Actual malignant tissue contained much less 5-HT than adjacent mucosa (Table II). The pyloric mucosa contained much less 5 -HT in cancer cases than in other cases $(P=0.02)$. The average value for the 5-HT concentration in the pyloric mucosa in cancer cases was $0.55 \mu \mathrm{g}$./g. compared with 3.3 $\mu \mathrm{g} . / \mathrm{g}$. for the other cases.

\section{TABLE II}

HISTAMINE AND 5-HT ASSAYS OF EXTRACTS FROM CARCINOMA COMPARED WITH THOSE FROM MUCOSA NOT SHOWING FRANK MALIGNANT CHANGE

\begin{tabular}{|c|c|c|c|c|c|c|}
\hline \multirow{2}{*}{$\begin{array}{l}\text { Case } \\
\text { No. }\end{array}$} & \multicolumn{3}{|c|}{ Histamine ( $\mu \mathrm{g} . / \mathrm{g})}$. & \multicolumn{3}{|c|}{$5-H T(\mu g . / g)}$. \\
\hline & Body & Pylorus & Cancer & Body & Pylorus & Cancer \\
\hline 13 & $11 \cdot 3$ & $3 \cdot 6$ & $0 \cdot 88$ & $0 \cdot 33$ & 0.22 & 0.029 \\
\hline 14 & 8.4 & 9.9 & $5 \cdot 6$ & $0 \cdot 10$ & 0.42 & 0.066 \\
\hline 15 & - & $19 \cdot 0$ & $5 \cdot 3$ & - & 0.72 & 0.060 \\
\hline 16 & 7.6 & - & $2 \cdot 4$ & 0.34 & - & 0.055 \\
\hline
\end{tabular}

SECTIONING TECHNIQUE Ten pieces of mucosa were examined by this technique. No simple pattern of distribution of histamine or of 5-HT emerged.

Usually histamine concentration was low in the 


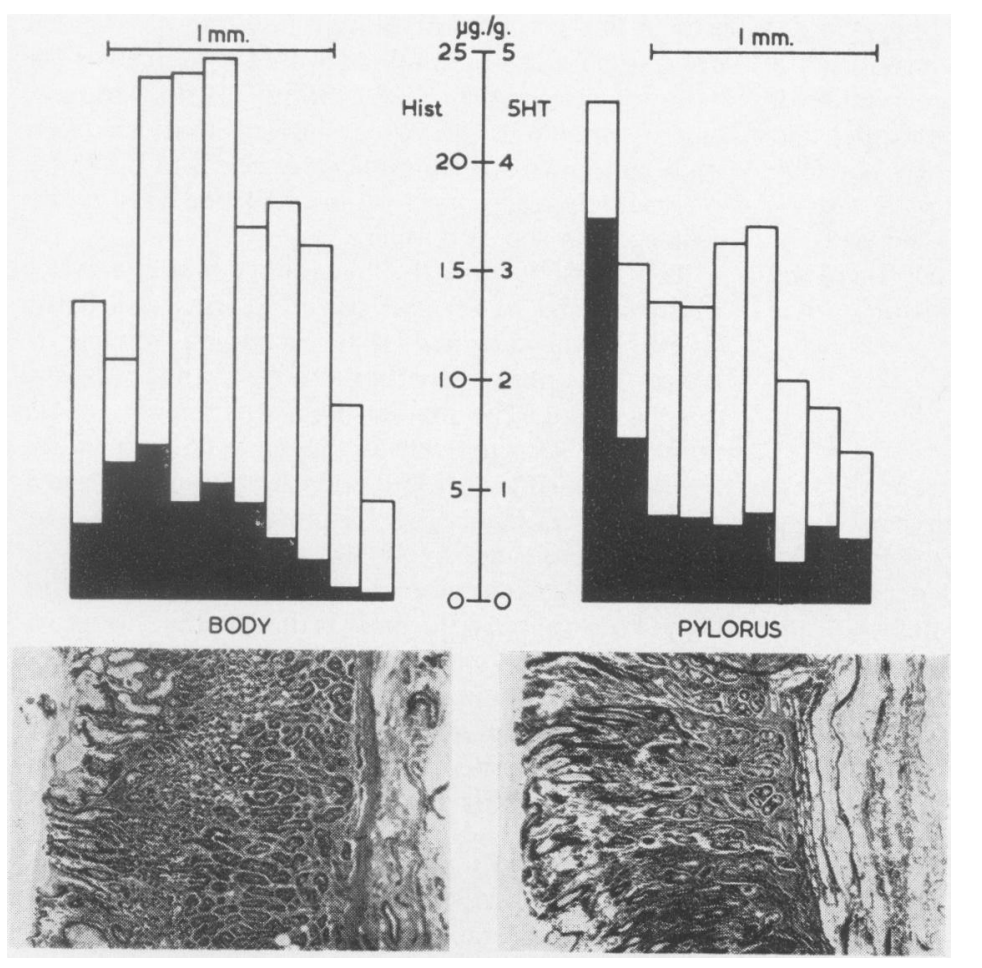

FIG. 1. Distribution of histamine and 5-hydroxytryptamine within the thickness of gastric mucosa.

Concentrations of histamine are shown by the total height of the clear columns and those of 5-hydroxytryptamine by the black columns. The horizontal scale of the histograms is the same as that of the photomicrographs below which show sections cut at right angles to the surface before cutting sections parallel to the surface for bioassay.

surface layer, increased towards the middle of the mucosa, and then fell towards the submucosa. This was true for both body and pylorus. In two experiments (one from body, one from pylorus) a high concentration of histamine was found in the surface layer. The large peak of histamine concentration near the muscularis mucosae described by Feldberg and Harris (1953) in the dog and by Smith (1959) in man was not demonstrated in any of our experiments. In half the experiments histological controls showed that the peak concentration of parietal cells (at the necks of the glands) did not correspond with the peak concentration of histamine found on assay.

The distribution of 5-HT within the thickness of the mucosa has not previously been studied. It was different from that of histamine in that 5-HT concentration always fell to low levels as the submucosa was approached and in pyloric specimens the highest 5-HT concentration was nearly always in the most superficial layer of the mucosa.

The results of typical experiments are shown in Figure 1.

ACTIVITY NOT DUE TO HISTAMINE OR TO 5-HT Tissue extracts prepared as described contain pharmacologically active components other than histamine and 5-HT. Histamine was considered to be respon- sible for virtually all the activity attributed to it since mepyramine maleate reduced in parallel contractions due to histamine and those due to the extracts. Chromatography of extracts showed that histaminelike activity was found in a single peak with an $\mathrm{Rf}$ indistinguishable from that of synthetic histamine.

Activity resistant to mepyramine $\left(10^{-7}\right.$ to $10^{-8}$ g./ml.) was present in all acid extracts. It was manifested by a slowly developing, but well maintained, rise in tone of guinea-pig ileum. The dose of extract required to produce a contraction was equivalent to 20 to $100 \mathrm{mg}$. of wet tissue. Activity was generally stronger in mucosa than in other layers, but not greatly so. Pyloric mucosa was a richer source than body mucosa, due, probably, in part to its higher 5-HT content. But strong activity was frequently present in muscle where it could not have been due to 5-HT. Such activity in acid extracts has usually been ascribed to substance $P$.

To see whether activity detected by the rat fundus preparation in acetone extracts was due solely to 5-HT we studied the effect of the specific 5-HT antagonist BOL-148; and we made chromatograms. We found that slow contracting activity remained after blocking 5-HT contractions with BOL; and that while the bulk of activity in acetone extracts had an $\mathrm{Rf}$ of 0.5 (indistinguishable from that 
of $5-\mathrm{HT}$ ), about $20 \%$ of it ran near the solvent front. This activity near the solvent front produced a characteristically slow contraction and relaxation of the fundus strip, was potentiated by hyoscine, and was not blocked by BOL. This activity is being studied further; present evidence suggests that it may be caused by a phospholipid. It seems to be different from the unidentified material found by Dalgliesh, Toh, and Work (1953) when they originally isolated 5-HT from the gut.

\section{DISCUSSION}

The mucosa of the gastrointestinal tract is very rich in pharmacologically active substances. It has always been attractive to ascribe certain functions to these substances though direct evidence of their specific activity has been very difficult to demonstrate. One of the criteria to be fulfilled before a substance can be considered to be a specific local chemostimulator is that the substance must be stored close to the effector cells. The present investigation does not support the idea that there is a specially high concentration of histamine in the immediate vicinity of the acid-secreting cells in the stomach of man. We found no evidence that there is a significantly higher concentration of histamine in the body mucosa than in the pyloric mucosa, where there are few or no acid-secreting cells. In a typical gastric gland from the body of the stomach, the acidsecreting cells are mainly congregated in the neck or mid portion of the tubule and there are none at the surface and few in the depths of the gland. In half of the sectioning experiments the peak histamine concentration did not correspond with the densest population of acid-secreting cells. The experiments of Trach, Code, and Wangensteen (1944) showed a higher average histamine content in body mucosa than in pyloric mucosa, but this was not statistically significant. Smith (1959) obtained results which, when converted to terms of histamine base, are similar to those in this paper. Douglas et al. (1951) examined the whole gastrointestinal tract in the dog and found just as much, or more, histamine in the proximal small bowel as in the body of the stomach. It seems unlikely that such concentrations of histamine in the duodenum are related to the stimulation of acid secretion in the stomach. These findings do not support the idea that histamine occurring naturally in the stomach is situated close to acid-secreting cells and is, therefore, likely to be the specific chemostimulator of acid secretion.

Perhaps the richest supply of histamine in the body is in mast cells; this histamine is easily released with the drug $48 / 80$. Mota, Beraldo, Ferri, and Junquiera (1956) have shown that there are few mast cells in the stomachs of animals and that most of the histamine must be contained within other cells since it is not released by $48 / 80$. Smith (1959), studying human stomachs in vitro, showed that relatively small amounts of histamine were released by $48 / 80$. Accordingly, there is as yet no evidence as to which cells contain the histamine.

It is possible that the histamine in the stomach wall is related to nervous tissue. Murray and Paton (1956) have indicated that histamine related to nerves is contained within the Schwann cells and not the axons. The smaller the axons the greater the number of Schwann cells in the nerve (Abercrombie, Evans, and Murray, 1959) and, therefore, the greater the amount of histamine. Histamine within Schwann cells is not released by $48 / 80$.

One interesting factor about the natural destruction of histamine in the body is the fact that histaminase or diamine oxidase, the enzyme system which deaminates histamine and thereby abolishes its physiological activity, is absent from the gastric mucosa. In contrast, there are considerable quantities of this enzyme elsewhere in the gastrointestinal tract, for example, in the ileum. It may be suggested that histamine in the gastric mucosa is in a preferred situation since it will not be destroyed by histaminase and this would argue towards the idea that minute amounts of histamine in the stomach might be more effective than elsewhere. This is in contrast to the acetylcholine-cholinesterase system where precision in activity is important. It is difficult to use this fact as an argument either for or against the physiological activity of histamine. The subject is reviewed by Code (1956) and it is fair to say that studies on histaminase have so far contributed little to our understanding of the physiological significance of histamine.

Although there is no close correlation between the histamine distribution and acid-secreting cells in the wall of the stomach, it could be argued that only a very small amount of histamine is required to stimulate the cells. Kahlson (1960) suggested a more dynamic approach, placing emphasis on the rate of formation and rapidity of turnover of histamine rather than on distribution alone. Schayer and Ivy $(1957,1958)$ provided evidence for this hypothesis when they showed that histidine labelled with carbon 14 when injected into rats is deposited as histamine in the stomach and later is released on feeding. In contrast Paton and Vane (1963) have shown that stimulation of the nerves in the stomach which would result in acid secretion does not release histamine. Nevertheless, they found that changes of pressure within the stomach which need not necessarily be associated with acid secretion result in the release of histamine. 
In the distribution of 5-HT in the human stomach there are two striking features. One is that the pyloric mucosa is always richer in 5-HT than the body mucosa, and the other that the bulk of the 5-HT is in the superficial layers of the mucosa. A high concentration in the pylorus has also been shown in the dog, though in the rabbit concentrations are higher in the body of the stomach (Feldberg, and Toh, 1953; Erspamer, 1954a and b). The finding that $5-\mathrm{HT}$ is in the superficial layers of the mucosa is surprising because this is not the distribution of the argentaffin cells which are supposed to contain the substance (Erspamer and Asero, 1952). Sharples (1945) studied the distribution of these cells in human stomachs and showed that they were more numerous in the body than in the pylorus and that they were confined to a narrow zone at the base of the glands. They were completely absent from the region of the foveolae where the highest concentration of 5-HT occurs.

The physiological role of 5-HT, a naturally occurring hormone in the gastro-intestinal tract, is still unknown. It has been shown by Smith (1958) and by Black, Fisher, and Smith (1958) that 5-HT infusions provoke a secretion of mucus in the stomach. Bülbring and Crema (1958), Beleslin and Varagić (1958), Lembeck (1958), and Haverback and Davidson (1958) demonstrated that $5-\mathrm{HT}$ is concerned with peristalsis in the gut, and it has been suggested by Bülbring and Crema (1958) that 5-HT lowers the threshold of stimulation of receptors in the intrinsic nerve plexuses in the bowel wall and thereby augments peristalsis. The distribution of 5-HT that we have shown in the human stomach, particularly in the superficial layers of the mucosa, does not detract from these conclusions.

Perhaps the most interesting feature about the distribution of 5-HT in pathological conditions is its low concentration in both the body and the pyloric mucosa in cases of cancer of the stomach. One possibility is that the low 5-HT concentration may be a result of the neoplastic process. If so, it is not simply a reflection of mucosal atrophy since two cases of benign gastric ulceration (10 and 11) showed severe atrophic gastritis but had high 5-HT levels. The second and more interesting possibility is that the low 5-HT levels may be a factor in the development of cancer. On a molecular basis 5-HT is the most potent known protector against the lethal effects of acute irradiation (Van den Brenk and Haas, 1961). Is it possible that the high concentration of 5-HT normally present in the superficial layers of the mucosa protects the cells against mutagenic agents in the stomach contents?

Although we can offer no suggestions about their physiological importance we have included some data on a substance with a P-like activity in our acid extracts and an acid lipid found in acetone extracts. The lipid material has not previously been described.

We wish to thank Mr. Harold C. Edwards, Professor W. C. Wilson, and other surgical colleagues for their help and encouragement. We are especially indebted to the Medical Research Council for a personal grant to one of us (J.G.M.).

\section{REFERENCES}

Abercrombie, M., Evans, D. H. L., and Murray, J. G. (1959). Nuclear multiplication and cell migration in degenerating unmyelinated nerves. J. Anat., 93, 9-14.

Babkin, B. P. (1950). Secretory Mechanism of the Digestive Glands, 2nd ed. Hoeber, New York.

Beleslin, D., and Varagic, V. (1958). The effect of cooling and of 5-hydroxytryptamine on the peristaltic reflex of the isolated guinea-pig ileum. Brit. J. Pharmacol., 13, 266-270.

Björkman, G., Norden, A., and Uvnäs, B. (1943). Histamine and peptic secretion. Acta physiol. scand., 6, 108-116.

Black, J. W., Fisher, E. W., and Smith, A. N. (1958). The effects of 5 -hydroxytryptamine on gastric secretion in anaesthetized dogs. J. Physiol., (Lond.) 141, 27-34.

van den Brenk, H. A. S., and Haas, M. (1961). Studies of mechanisms of chemical radiation protection in vivo. 1. 5-hydroxytryptamine in relation to effect of antimetabolies, antagonists and releasing agents. Int. J. Radiat. Biol., 3, 73-94.

Bülbring, E., and Crema, A. (1958). Observations concerning the action of 5-hydroxytryptamine on the peristaltic reflex. Brit. J. Pharmacol., 13, 444-457.

Clark, C. G., Curnow, V. J., Murray, J. G., Stephens, F. O., and Wyllie, J. H. (1964). The mode of action of histamine in causing gastric secretion in man. Gut, $5,537-545$.

Code, C. F. (1956). Histamine and gastric secretion. In Ciba Symposium on Histamine, edited by G. E. W. Wolstenholme and C. M. O'Connor, pp. 189-219. Churchill, London.

Dalgliesh, C. E., Toh, C. C., and Work, T. S. (1953). Fractionation of the smooth muscle stimulants present in extracts of gastrointestinal tract: identification of 5-hydroxytryptamine and its distinction from substance P. J. Physiol., (Lond.), 120, 298-310.

Douglas, W. W., Feldberg, W., Paton, W. D. M., and Schachter, M (1951). Distribution of histamine and substance $P$ in the wall of the dog's digestive tract. Ibid., 115, 163-176.

Erspamer, V. (1954a). Pharmacology of indolealkylamines. Pharmacol. Rev., 6, 425-487.

__ (1954b). Quantitative estimation of 5-hydroxytryptamine in gastro-intestinal mucosa, spleen and blood of vertebrates. In Ciba Symposium on Hypertension, edited by G. E. W. Wolstenholme and M. P. Cameron, pp, 78-90. Churchill, London.

- and Asero, B. (1952). Identification of enteramine, the specific hormone of the enterochromaffin cell system, as 5-hydroxytryptamine. Nature (Lond.), 169, 800-801.

Feldberg, W., and Harris, G. W. (1953). Distribution of histamine in the mucosa of the gastro-intestinal tract of the dog. J. Physiol. (Lond.), 120, 352-364.

- and Toh, C. C. (1953). Distribution of 5-hydroxytryptamine (serotonin, enteramine) in the wall of the digestive tract. Ibid., 119, 352-362.

Haverback, B. J., and Davidson, J. D. (1958). Serotonin and the gastrointestinal tract. Gastroenterology, 35, 570-578.

Kahlson, G. (1960). A place for histamine in normal physiology. Lancet, 1, 67-71.

Lembeck, F. (1958). Carcinoids and the significance of 5-hydroxytryptamine. In 5-Hydroxytryptamine, edited by G. P. Lewis, pp. 147-152. Pergamon Press, London.

Linde, S. (1950). Studies on the stimulation mechanism of gastric secretion. Acta physiol. scand., 21, suppl. 74.

Magnus, H. A. (1958). A re-assessment of the gastric lesion in pernicious anaemia. J. clin. Path., 11, 289-295.

Mota, I., Beraldo, W. T., Ferri, A. G., and Junqueira, L. C. U. (1956). Action of $48 / 80$ on the mast cell population and histamine content of the wall of the gastrointestinal tract of the rat. In Ciba Symposium on Histamine, edited by G. E. W. Wolstenholme and M. O'Connor, pp. 47-50. Churchill, London. 
Murray, J. G., and Paton, W. D. M. (1956). In Ciba Symposium on Histamine, edited by G. E. W. Wolstenholme and M. O'Connor p. 451. Churchill, London.

Parratt, J. R., and West, G. B. (1957). 5-hydroxytryptamine and tissue mast cells. J. Physiol. (Lond.), 137, 169-178.

Paton, W. D. M., and Vane, J. R. (1963). An analysis of the responses of the isolated stomach to electrical simulation and to drugs. Ibid., 165, 10-46.

Schayer, R. W., and Ivy, A. C. (1957). Evidence that histamine is a gastric secretory hormone in the rat. Amer. J. Physiol., 189. 369-372.

- - (1958). Release of C14-histamine from stomach and intestine on feeding. Ibid., 193, 400-402.
Sharples, W. (1945). A note on the relatively high number of argentaffin cells in the mucosa of the human stomach. Anat. Rec., 91. 237-342.

Smith, A. N. (1958). The effect of 5-hydroxytryptamine on acid gastric secretion. In 5-Hydroxytryptamine, edited by G. P. Lewis. pp. 183-190. Pergamon Press, London.

- (1959). The distribution and release of histamine in human gastric tissues. Clin. Sci., 18, 533-541.

Trach, B., Code, C. F., and Wangensteen, O. H. (1944). Histamine in human gastric mucosa. Amer. J. Physiol., 141, 78-82.

Vane, J. R. (1957). A sensitive method for the assay of 5-hydroxytryptamine. Brit. J. Pharmacol., 12, 344-349.

\section{The October 1964 Issue}

\section{THE OCTOBER 1964 ISSUE CONTAINS THE FOLLOWING PAPERS}

Dose-response curves for the effect of gastrin II on acid gastric secretion in man G. M. MAKHLOUF, J. P. A. MCMANUS, and W. I. CARD

The absorption of radioactive vitamin $B_{12}$ and the secretion of hydrochloric acid in patients with atrophic gastritis M. G. WHITESIDE, D. L. MOLLIN, N. F. COGHILL, A. WYNN WILLIAMS, and BARBARA ANDERSON

Note on the late effect of vagotomy and pyloroplasty on the maximal acid response to histamine ALVIN M. GELB and HENRY D. JANOWITZ

Gastric ulcers, blood groups, and acid secretion $H$. DAINTREE JOHNSON, A. H. G. LOVE, N. C. ROGERS, and A. P. WYATT

Peptic ulcer in India and its aetiology s. L. MALHOTRA

Peptic ulcer and gastric secretion in patients with liver disease SOAD TABAQCHALI and A. M. DAWSON

Reduced gastric acid output in cirrhosis: Quantitation and relationships BRIAN A. SCOBIE and WILLIAM H. J. SUMMERSKILL

Spontaneous internal biliary fistulae J. L. A. DOWSE

Controlled trial of sulphasalazine in the treatment of ulcerative colitis A. P. DICK, M. J. GRAYSON, R. G. CARPENTER, and A. PETRIE

Motility of the pelvic colon

Part III Motility responses in patients with symptoms following amoebic dysentery A. M. CONNELL, M. GAAFER, M. A. HASSANEIN, and M. A. KHAYAL
Periampullary and duodenal carcinoid tumours KENNETH W. WARREN, WILlIAM M. MCDONALD, and C. J. HUME LOGAN

Experimental production of gastric epithelium in the duodenum J. RHODES

Hyperplasia of Brunner's glands J. F. STOKES, L. A. TURNBERG, and J. C. HAWKSLEY

Effect of paracetamol ( $\mathrm{N}$-acetyl-p-aminophenol) on gastrointestinal bleeding KERRY GOULSTON and ALAN SKYRING

Fixation of sulphur in the gut by bismuth salts J. T. WRIGHT and J. GUPTE

Some effects of hypophysectomy on gastrointestinal function and structure E. D. JACOBSON and T. J. MAGNANI with the technical assistance of E. B. MCCLASKEY and T. J. KALLAL

Hydrolysis of fat by human gastric juice S. BANK, L. H. KRUT, I. N. MARKS, B. BRONTE-STEWART, and P. J. LE R. UYS

\section{Methods and techniques}

Peritoneoscopy as an aid to diagnosis IVAN D. A. JOHNSTON and $\mathrm{H}$. W. RODGERS

Experience of a new procedure for faecal analysis w. C. WATSON and CHRISTINE DICKSON

Gastroenterological Society of Australia

Copies are still available and may be obtained from the PUBLISHING MANAGER. BRITISH MEDICAL ASSOCIATION, TAVISTOCK SQUARE, W.C.I., price 18s. 6D. 